\title{
Three-dimensional microscopy of the human bronchial mucosa
}

\author{
Melissa Suter, David Riker*, Brett Bouma, John Beamis, Guillermo Tearney \\ From 2nd Scientific Meeting of the Head and Neck Optical Diagnostics Society \\ San Francisco, CA, USA. 23-24 January 2010
}

\section{Introduction}

Lung cancer is the leading cause of cancer related death, and despite recent efforts to reduce the mortality associated with the disease, patient prognosis remains poor with the current 5 -year survival rate under $15 \%$. Detection and diagnosis of lesions arising in the bronchial mucosa remains problematic and as a result they are typically well advanced upon discovery.

\section{Methods}

We are currently conducting a clinical study aimed at using optical frequency domain imaging (OFDI) to interrogate the bronchial mucosa of patients with the suspicion of lung cancer. During bronchoscopic evaluation, regions of interest suspicious for cancer or precursor lesions were identified and imaged, in addition to regions of normal appearing mucosa. Following OFDI imaging, mucosal biopsies were obtained for histopathologic analysis. Spiral cross-sectional OFDI images were obtained at a rate of 50 frames/sec using a 2.4 Fr catheter (frame size: 1536x1024; image resolution: $8 \mu \mathrm{m} \mathrm{x}$ $23 \mu \mathrm{m} \times 100 \mu \mathrm{m})$.

\section{Results/conclusions}

The layered structure of the normal bronchial mucosa was clearly visualized in the OFDI images including the identification of the epithelium, lamina propria, smooth muscle, perichondrium and cartilage layers. In addition, features such as mucosal vasculature, glands, ducts and alveoli were observed. Various features associated with airway disease were also observed including the presence of fibrous debris, airway inflammation, and lymphatic and blood vasculature remodeling. Based on these preliminary results we anticipate that OFDI imaging of the pulmonary airways will enable the early detection of

Lahey Clinic Medical Centre, Burlington, USA airway features associated with the development of cancer. When used as a screening tool in high-risk patients we hope that early detection of airway associated cancer with OFDI will result in a decrease in patient mortality.

Acknowledgements

Olympus Corporation, K99 CA134920

Published: 29 October 2010

doi:10.1186/1758-3284-2-S1-013

Cite this article as: Suter et al:: Three-dimensional microscopy of the human bronchial mucosa. Head \& Neck Oncology 2010 2(Suppl 1):013.

Submit your next manuscript to BioMed Central and take full advantage of:

- Convenient online submission

- Thorough peer review

- No space constraints or color figure charges

- Immediate publication on acceptance

- Inclusion in PubMed, CAS, Scopus and Google Scholar

- Research which is freely available for redistribution

Submit your manuscript at www.biomedcentral.com/submit 